\title{
衛星マルチスペクトルデータを適用した分級評価モデルの開発

\author{
DEVELOPMENT OF LAND USE CAPABILITY CLASSIFICATION MODEL \\ APPLYING SATELLITE MULTI-SPECTRAL SCANNER DATA
}

\author{
小島尚人*·大林成行** \\ By Hirohito KOJIMA and Shigeyuki OBAYASHI
}

\begin{abstract}
Reseach on the land use investigation using satellite data is being carried out very actively. We have developed "Latency Factor (LF) model" for the land use capability classification and evaluation. Points to which special attention should be paid are that satellite data and geographical information are defined as latency factors in the land. LF model doesn't evaluate a value in use of the land but a potential value or a value of existence in the land. The analysis processes are as follows : 1) Quantification Method Type III are used to analyze the causality between latency factors. 2) The land use capability classification map is made by Quantification Method Type II and the min-max method distinguishing areas resembled training data.

Furthermore. LF Model has the three evaluation processes called "Present situation type", "Normative type" and "Hypothetical type". By comparison of classification maps of the farm land made by LF model and the former grading method. LF Model is very useful for extracting appropriate areas.
\end{abstract}

Keywords: land use capability classification, remote sensing, land use plan (and planning) quantification method, geographical information

\section{1.はじめに}

現在, 衛星マルチスペクトルデータの利用範囲は海洋 観測, 森林管理, 環境モニタリング等, 多岐にわたって いる. しかし, 衛星マルチスペクトルデータの処理／解 析技術は基礎研究段階から実用研究段階へ之進展し, 数 多くの要素技術が蓄積されてきてはいるものの, 利用 ニーズに応じた処理／解析手法を 1 つの体系として整理 し, 建設分野等, 実際の事業計画へ有効に利活用してい る事例はそれほど多くみられない.このような状況の中, 最近の衛星データの利用動向をみると衛星データを単独 で利用するというよりも, 数值地形モデル (DTM : Digital Terrain Model) 加ら得られる種々の情報や地 形, 地質, 土壌といったさまざまな国土に内在する情報 (以下, 本研究ではこれらの情報を「国土に内在する潜 在因子」とよぶ）を融合利用することによって, 土地利 用計画, 農地振興計画, 緑化計画等, 国土の面的な調査, 計画の分野への実用化研究がさかんに行われるように なってきだ). 諸外国では, GIS (Geographical In-

* 正会員 東京理科大学助手 理工学部土木工学科 ( (278 野田市山崎 2641)

** 正会員 工博 東京理科大学教授 理工学部土木工学科 (同上) formation system) とリモートセンシングを融合利用し， 付加価値のある情報を抽出する研究も多い2).

国土の面的な評価手法には, 土地の地価変動や人口流 動, 交通条件, 経済資質等を考慮に入れたさまざまな土 地評価モデル，土地利用モデルが考案されている31. 土 地の評価といってもそれらをどのような視点からとらえ るのかによって, 取り扱う評価の目的と方法は大きく異 なる，さらに，実際に評価を進めるうえで，多くの前提 条件や制約条件があることや, 一意的な評価モデルであ るために他地域には適用することができない等, 実用的 な評価プロセスが求められている.

本研究では第 4 次全国総合開発計画にも重要課題とし て取り上げられている「土地利用計画の最適化」といっ た問題に対して従来から考案され利用二ーズが高い「土 地分級評価」に着目し，「国土の評価／計画」と「衛星 マルチスペクトルデータの実利用化」といった問題を両 面から論ずる研究命題を設定する. 国土 (狭義には土地) に内在する価值を「空間価值」としてとらえ ${ }^{3), 4)}$, 衛星 マルチスペクトルデータをはじめとした国土にかかわる 種々の面的な情報を組み込むことができる新たな土地分 級評価モデル, いわゆる本研究で提案する「潜在因子モ デル」を開発する. 


\section{2. 研究の目的}

本研究の目的は以下の 3 点である.

(1) 国土の評価手法として従来から考案され，利用 二ーズの高い分級評価手法の問題点を抽出, 整理し, こ れをもとに新たな分級評価の考え方を提案する.

(2) (1)で提案した分級評価の考え方に従って実際に分 級評価モデル（以下，「潜在因子モデル」とよぶ）のプ ロトタイプを開発する。

（3) 従来の分級評価手法と本研究で開発した潜在因子 モデルを用いて実際に分級評価図を作成し，結果を相互 比較するとともに潜在因子モデルの有用性を示す。

また，本文の構成は図一1 に示すとおりである．以下， この流れに従って順を追って説明する.

\section{3. 土地分級評価の問題点 ${ }^{5)}$}

「土地分級評価」とは，土地がもつ「空間価值（使用 価值, 存在価值, 潜在価値)」をいくつかの等級に区分し, 自然的，社会的，経済的な諸条件に基つういて，その土地 の価值を分析することにより，現在あるいは将来に向け ての最適な土地利用形態を形成すること」を目的とした 国土の評価手法の1つであり, 土地利用計画にいうマク ロ的な視点とミクロ的な視点の中間に位置する.

わが国における土地分級論は農林水産技術会議を中心 とした研究グループによる「新しい農村計画のための土

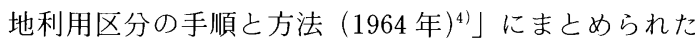

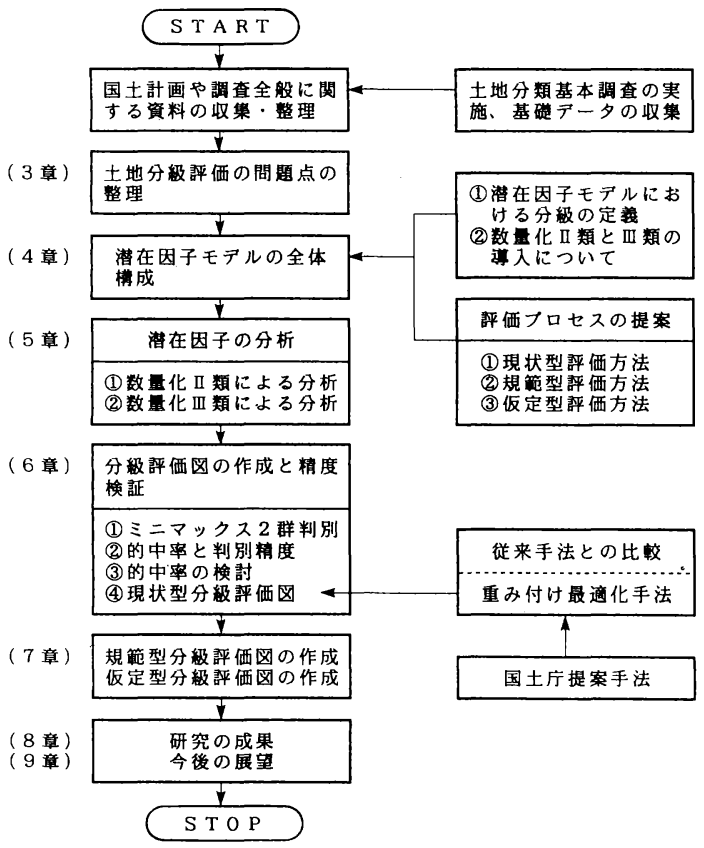

図一1研究の流れ
研究を出発点としている。現状では土地分級論がようや く土地利用計画手法の 1 つとして位置付けられ，その方 向性が見出されてきたばかりという状況にある。このよ うな分級評価にかかわる問題点を整理すると大きく分け て次の 4 つの項目が挙げられる.

(1) 分級評価要因の設定の問題

(2) 分級評価基準の設定の問題

（3）評価項目毎に適用すべき分級評価手法の選定の問 題

(4) 分級評価精度の評価方法の問題

これらの内容については参考文献 5) にて詳述してあ るので割愛するが，この問題点をもとに，本研究では分 級評価プロセスの望ましい姿を図一2のように整理し た.すなわち, 分級評価項目と分級評価要因間, さらに は分級評価要因間の因果関係分析が行えるモデルとする 必要がある．本研究で開発した潜在因子モデルでは，分 級評価項目と分級評価要因間の分析に数量化 II 類を，分 級評価要因間の分析に数量化四類を導入し，分級評価図 作成においてはミニマックス 2 群判別を用いる。なお, 潜在因子モデルは, 空間価値のうち「潜在価値」, 「存在 価值」を取り扱うものであり，「使用価值」の評価は「財」 としての土地評価論との関連性を論ずる研究に委ねるこ ととし, 今後の課題としたい.

\section{4. 潜在因子モデル}

\section{（1）潜在因子モデルの全体構成6}

潜在因子モデルの全体構成を図一3に示す。すなわち， 衛星デー夕をはじめとする種々の潜在因子と目的とする 評価項目 (外的基準) との関連性を数量化 II 類によって 分析するとともに，算出される個体数量に対するミ二 マックス 2 群判別の処理プロセスの組合せによって構成 される。これによって, 従来から利用されているランク 分けによる分級評価結果の曖昧性を排除した。 そして, 外的基準を設定しない潜在因子間のデータ構造の分析を

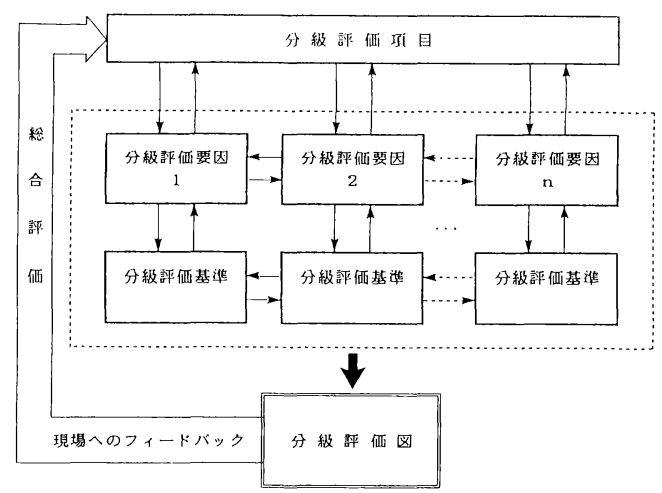

図一2＼cjkstart望ましい分級評価プロセス 


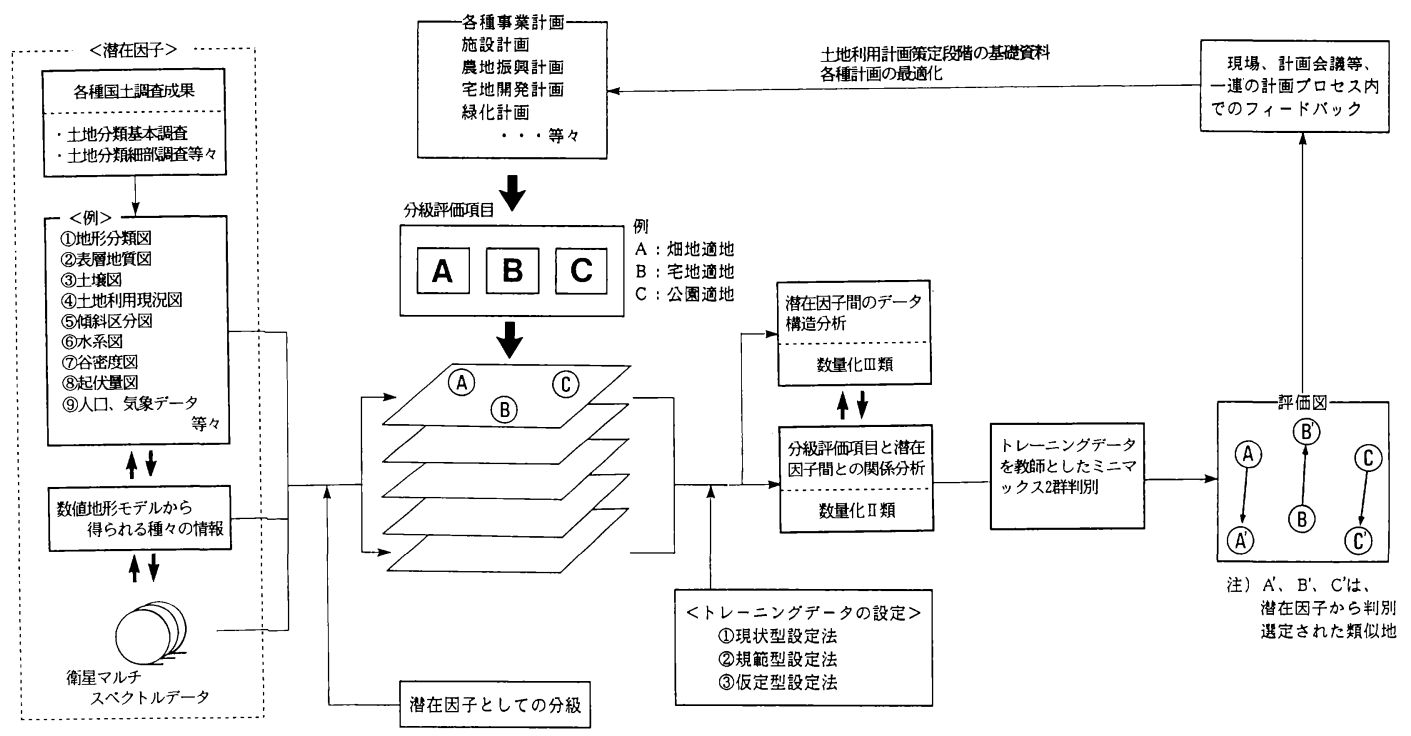

図一3 潜在因子モデルの全体構成

数量化 III類に受け持たせることによって, 分級評価要因 間の関連性をとらえることの可能なモデルを指向した (前述の問題点(1), (2)に対応). さらに 2 群判別問題で 使用するトレーニングデータの設定方法の違いによって (1)現状型，(2)規範型，(3)仮定型といった3つの評価方法 を提案し, 評価プロセス時の意思決定に寄与できるシス テムとして構成した.

土地分級評価手法は, 斜面崩壊危険地域や洪水氾濫危 険地域の評価等にも適用される。したがって，このよう な防災分野においても, 土地に内在する潜在的な営力を 評価するといった視点から潜在因子モデルの「現状型評 価プロセス」が適用できる，著者らは，すでに潜在因子 モデルの現状型評価プロセスを斜面崩壊予測問題に適用 し，その有効性を立証している7). 本研究ではさらにス テップを進め,「規範型」,「仮定型」といった評価プロ セスを組み込み，種々の評価項目に対応できる体系化し た分級評価モデルとした。

\section{（2）潜在因子モデルにおける分級の定義}

従来の分級の概念は, 個々の潜在因子に対して評価項 目を説明する評点を与え, 各種の評価モデルによって数 值処理していた。これはエキスパートシステムにおける ルールの記述やファジィ理論におけるファジィ関数決定 の段階にも相当する.しかし，評点を与える段階で不明 確な要因が介入し，さらに数值処理された分級結果には '信頼性の問題が指摘されていることは前述した問題点(3) に示したとおりである. そこで，本研究における「分級」 とは, 図一4に示すように「評価対象メッシュが潜在因 子のよ゙の項目に属するのかといった現状の土地の状況に 即した判定処理」と定義する.

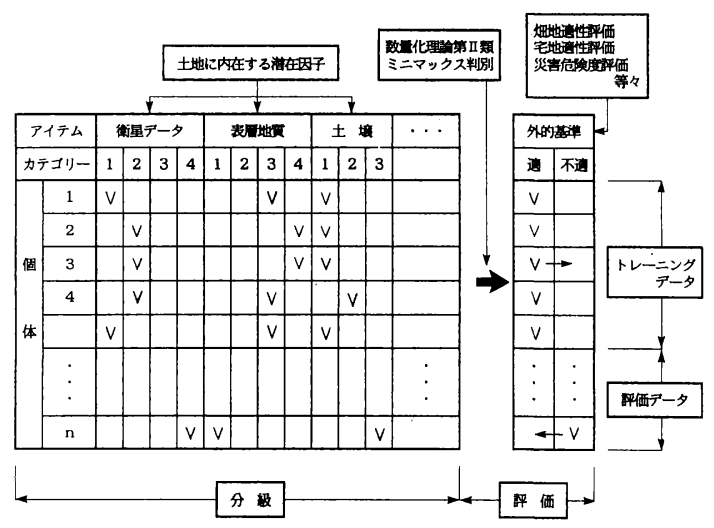

図一4＼cjkstart潜在因子モデルにおける「分級」と「評価」

ここでいうカテゴリーは，たとえば土壌アイテムの場 合, $1 \rightarrow$ 黒ボク土壌, $2 \rightarrow$ 粗粒黒ボク土㙵といった凡例 項目に対応する. 従来の分級では黒ボク土壌, 粗粒黒ボ ク土壌等の凡例項目に対して, 外的基準 (畑地適性の有 無等) を説明するためにあらかじめ数量を与えて分級評 価基準を作成していた。しかし，図一4では個体がよ゙の 凡例項目に反応するのかといった現象のみに着目してカ テゴリ一反応マトリックスを作成する。この段階を「分 級」として新たに定義する.

衛星データを数量化理論のアイテムの 1 つに組み込む 場合, 従来この方面の研究では衛星デー夕の情報を用い て別のアイテム (宅地可能性面積等) を設定したり ${ }^{1}$, 単バンドデータの画像濃度值の範囲を数段階に区切っ て, 質的データに置き換えて適用することが多く ${ }^{8)}$, 検 討ケースごとに衛星データの質や算出されるパラメー 
ターの精度に大きく左右される. そこで, 本研究では, あくまでも多次元で構成される画像濃度值の情報を集約 化（クラスタリング）したうえで，1つのアイテムとし て潜在因子モデルに組み込み汎用性をもたせる。なお， 衛星データのクラスター分析は，他の手法に比べて分類 精度が高く，比較的よく用いられるISO-DATA 法を採 用した。

\section{（３）潜在因子モデルにおける3つの評価プロセス}

潜在因子モデルの評価プロセスは, ミニマックス 2 群 判別の基準となるトレーニングデータの設定方法の違い によって，図一5に示したように(1)現状型，(2)規範型，

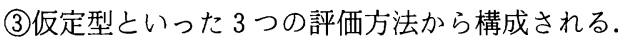

(1) 現状型評価プロセス

現状型評価とは現地調査結果や土地利用現況図等か ら, 現状が評価適地である箇所（たとえば畑地適性評価 ならば現状が畑地である箇所）をトレーニングデータと して設定し，このデータに最も性質が似通った類似地を 選定するものである. 現状の土地の状況を忠実に反映さ せる判別の考え方であり，土地利用計画策定段階におけ る最も基本となる評価方法として位置付けられる。

(2) 規範型評価プロセス

このプロセスは, 現状型評価プロセスで設定したト レーニングデータに加え，評価者や専門家の知見を付加 し，規範的にトレーニングデータを設定して分級評価図 を作成するものである，規範型分級評価図と現状型分級 評価図との違いをとらえることによって規範的要因に寄

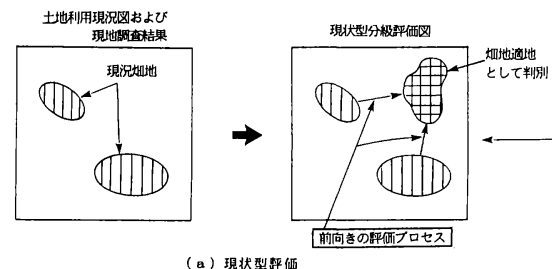

(a) 現状型粰佂

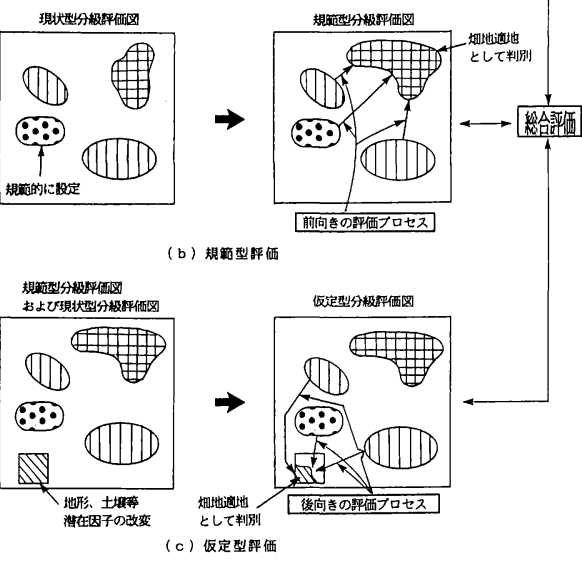

図一5＼cjkstart潜在因子モデルにおける評価プロセス
与する適地を抽出することが可能となる，規範型評価プ ロセスは潜在因子モデルの必要不可欠な構成要素であ る.

(3) 仮定型評価プロセス

この評価プロセスは，ある潜在因子 (傾斜，土壌等) を人為的に変化させたと仮定してトレーニングデー夕を 設定し, その改変地域が適地と判断できるか否かを評価 するものである．現状型および規範型評価プロセスは, トレーニングデータを基準として未知の類似地を選定す ることから，これら 2 つ評価プロセスをトレーニング データに対する「前向きの評価プロセス」とするならば， 仮定型評価は「後ろ向きの評価プロセス」とよぶことも できる。

\section{5. 潜在因子の分析}

\section{（1）設定した潜在因子と対象領域}

潜在因子モデルを構築するにあたって，国土計画，保 全の意味できわめて重要な問題となっている農用地（畑 地）適性をテスト主題として設定した ${ }^{11)}$.

畑地適性を評価するうえで設定した潜在因子を表一1 に示す。また，対象領域は昭和 63 年度土地分類基本調 査の一環として国土庁と東京都の指導のもとに東京理科 大学リモートセンシング研究所が実施し ${ }^{121}$, グランドト ルースデータが完備されている東京都大島町とした。な お, 現地調査と航空写真判読によって設定したトレーニ ングデータは, 写真一1 の赤色および青色で示された画 素である．この色のもつ意味については後述する.

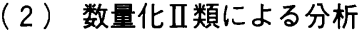

表一1で示した潜在因子を説明変量に, 畑地「適・不

\section{表一1＼cjkstart設定した潜在因子（東京都伊豆大島対象）}

\begin{tabular}{|c|c|c|c|c|}
\hline \multicolumn{3}{|c|}{ 土地分疑基本調查成果困 } & \multicolumn{2}{|c|}{ DTMから作成 } \\
\hline 地形分類因子 & 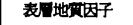 & 土境肉子 & 斜面方位因子 & 借斜区分因子 \\
\hline 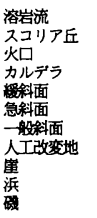 & $\begin{array}{l}\text { 玄武岩溶岩流 } \\
\text { スバタースコリア } \\
\text { 降下火山灰 } \\
\text { 砂、 } \\
\text { 火口 } \\
\text { 海 }\end{array}$ & 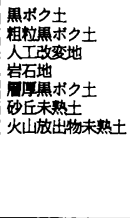 & $\begin{array}{l}\text { 北 } \\
\text { 北東 } \\
\text { 東 } \\
\text { 南東 } \\
\text { 南 } \\
\text { 南西 } \\
\text { 西 } \\
\text { 北西 } \\
\text { 平地 }\end{array}$ & $\begin{array}{c}\text { 以上〜末渵 } \\
\text { (度) } \\
0 \sim 3 \\
3 \sim 8 \\
8 \sim 15 \\
15 \sim 20 \\
20 \sim 30 \\
30 \sim\end{array}$ \\
\hline \multicolumn{3}{|c|}{ DTMから作成 } & \multirow{2}{*}{\multicolumn{2}{|c|}{ 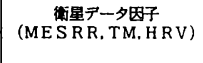 }} \\
\hline 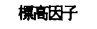 & 起伏因子 & 谷密莚的子 & & \\
\hline 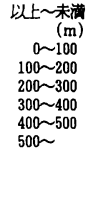 & $\begin{array}{c}\text { 以上 未满 } \\
(\mathrm{m}) \\
0 \sim 3 \\
3 \sim 6 \\
6 \sim 9 \\
9 \sim 12 \\
12 \sim 15 \\
15 \sim 20 \\
20 \sim 25 \\
25 \sim 30 \\
30 \sim\end{array}$ & $\begin{array}{ll} & \text { (個) } \\
0 & \\
1 & \\
2 & \\
3 & \\
4 & \\
5 & \end{array}$ & 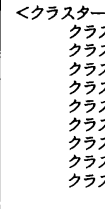 & $\begin{array}{l}\text { 解析画像> } \\
11 \\
22 \\
33 \\
4 \\
25 \\
6 \\
7 \\
78 \\
9\end{array}$ \\
\hline
\end{tabular}

注1）DTMはランドサットTMアータと合わせるために 1 メシュュ30 mで作成した

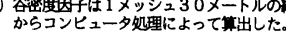

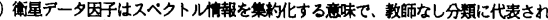
るクラスター解析 (ISO-DATA法) による分頑画像を整在肉子として取り入れた。 
表一2 数量化П類による分析結果

\begin{tabular}{|c|c|c|c|c|c|c|c|}
\hline & 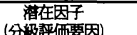 & カテコリ & 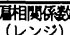 & & 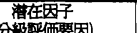 & カテコリ & 辰相間係 \\
\hline & 溶岩流 & 0.190 & & & (以上〜末渵: $\mathrm{m}$ ) & & \\
\hline & スコリア丘 & -0.182 & & 櫂 & $0 \sim 100$ & 0.422 & \\
\hline 地 & 火口 & -0.034 & & 高 & $100 \sim 200$ & -0.082 & 0.114 \\
\hline 形 & $\begin{array}{l}\text { カルデラ } \\
\text { 跎料面 }\end{array}$ & $\begin{array}{l}-0.506 \\
-0.001\end{array}$ & & 因 & $\begin{array}{l}200 \sim 300 \\
300 \sim 400\end{array}$ & -0.308 & $(0.730)$ \\
\hline 霜 & 繁科颣面 & $\begin{array}{r}-0.001 \\
0.123\end{array}$ & $(1.207)$ & & $\begin{array}{l}300 \sim 400 \\
400 \sim 500\end{array}$ & $\begin{array}{l}-0.206 \\
-0.188\end{array}$ & \\
\hline 因 & 一般鈄面 & 0.097 & & & $500 \sim$ & & \\
\hline 子 & 人工改変地 & $\begin{array}{l}-0.054 \\
-0.852\end{array}$ & & & (以上〜末涌：m) & 0.336 & \\
\hline & 浜 & 0.085 & & 起 & $3 \sim 6$ & -0.037 & 0.055 \\
\hline & 磁 & -1.018 & & 获 & $6 \sim 9$ & -0.070 & $(0.600)$ \\
\hline 表 & 玄武岩溶岩流 & 0.062 & & 鳤 & $9 \sim 12$ & -0.124 & \\
\hline 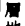 & スパタースコリア & & & 㐁 & $12 \sim 15$ & -0.199 & \\
\hline 地 & 降下火山灰 & -0.017 & 0.043 & 子 & $15 \sim 20$ & -0.166 & \\
\hline 贾 & 砂酸 & $\begin{array}{r}-0.041 \\
0.257\end{array}$ & (3.002) & & $\begin{array}{l}20 \sim 25 \\
25 \sim 30\end{array}$ & $\begin{array}{r}-0.170 \\
0.069\end{array}$ & \\
\hline 至 & 海 & -2.745 & & & $30 \sim$ & 0.401 & \\
\hline & 勲ホク土 & 0.432 & & 谷 & （個） & -0.009 & \\
\hline 土 & 粗粒埋ボク土 & 0.132 & & 密 & 1 & -0.037 & \\
\hline 壤 & 人工改変地 & -1.127 & 0.194 & 度 & 2 & 0.048 & 0.018 \\
\hline 因 & 岩石地 & -0.046 & (1.559) & 因 & 3 & -0.076 & $(0.428)$ \\
\hline & 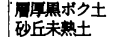 & $\begin{array}{l}-0.955 \\
-1.006\end{array}$ & & 子 & $\begin{array}{l}4 \\
5\end{array}$ & $\begin{array}{l}-0.136 \\
-0.380\end{array}$ & \\
\hline & 火山放出物来勢士 & -0.0 & & & 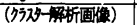 & & \\
\hline & 北 & 0.0 & & 推 & クラス1 & .099 & \\
\hline & 北東 & 0.1 & & & & -0.436 & \\
\hline 面 & 東 & & & $\bar{F}$ & & -0.416 & 0.22 \\
\hline 方 & 南東 & 0.575 & 0.090 & 1 & クラス4 & 0.277 & $(1.972)$ \\
\hline 位 & 南 & 0.393 & (2.872) & 夕 & クラス5 & 1.176 & \\
\hline 因 & 南西 & $\begin{array}{r}-0.238 \\
0.041\end{array}$ & & 因 & $\begin{array}{l}\text { クラス6 } \\
\text { クラス7 }\end{array}$ & $\begin{array}{l}-0.065 \\
-0.367\end{array}$ & \\
\hline & 北西 & & & & & & \\
\hline & 平地 & & & & & & \\
\hline 傎 & $a \sim 3$ & & & & 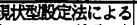 & & \\
\hline 斜 & $\begin{array}{l}3 \sim 8 \\
8 \sim 15\end{array}$ & $\begin{array}{r}0.050 \\
-0.144\end{array}$ & & 外 & トレーニンダータ & 1.540 & \\
\hline 分 & $\begin{array}{l}15 \sim 20 \\
20 \sim 30\end{array}$ & $\begin{array}{l}-0.213 \\
-0.303\end{array}$ & $(0.927)$ & 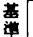 & 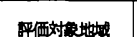 & -0.147 & \\
\hline 子 & $30 \sim$ & -0.423 & & & (現呮姆地以外) & & \\
\hline
\end{tabular}

適」といった 2 つの情報を外的基準とし, 数量化 II 類に よって分析した結果を表一2に示す.レンジ，偏相関係 数, 相関比とも非常に小さい值を示すことから, 設定し た潜在因子によって外的基準を説明する際には，数値の 微妙な変動をとらえることが重要となる.

レンジと偏相関係数は, ともに大きい順にそのアイテ ムが外的基準に寄与しているものであるから，本来その 順位は同一になるはずである.しかし，図一7に示すよ うに数量化された個体の分布状態が正規分布に従わない 場合には，表層地質のようにレンジの值が極端に大きく なることもある.多くのカテゴリーに細分化されたアイ テムとか, サンプルの反応の少ないカテゴリーは, 他の カテゴリーと比較して信頼度が低くなる ${ }^{9)}$. 特に本研究 のように地理情報を扱う場合, このような現象が現われ やすい.レンジのみの順位から外的基準への寄与の影響 度を評価することは危険であり，0〜1に正規化されて 算出される偏相関係数が有用亡なる場合もあるといわれ ている(10).

これらの点に注意してレンジや偏相関係数をみてみる と, 経験的に畑地適性に関係があると考えられる土壌因 子や畑地の被覆状況をスペクトル情報としてとらえるこ とができる衛星データ因子は, 他の潜在因子に比べて相 対的に高い順位に位置し, 外的基準を説明するうえで寄 与するものと判断できる．また，畑地適性の「有・無」 といった $2 つ の$ 質的事象がカテゴリー数量の正, 負に よって区別できることもわかる.

さらに細かくみてみると, 斜面方位因子で南西だけの
カテゴリー数量が負 (畑地として不適) を示し, 起伏量 $\lceil 0 \sim 3 \mathrm{~m} 」 お よ ひ ゙ 「 25 \mathrm{~m}$ 以上」で正 (畑地として適地) となっているが, これは, 本研究で設定した畑地として のトレーニングデータの性質が反映されているためであ る.このように潜在因子モデルでは，トレーニングデー 夕を介して地域の特性を取り込むことができ, 汎用性を もたせている.

以上の分析結果を踏まえて, 後述する分級評価図作成 のための「ミニマックス 2 群判別手法」の導入へと展開 する。

\section{（3）数量化III類による分析}

数量化 III 類では外的基準を設定せず潜在因子間のみの 関連性を分析する.これは，3. で述べた分級評価の問 題点(1)に対応するものである．具体的には,

a) トレーニングデータに着目しながら潜在因子間の

関連性をとらえる。

b ）設定した潜在因子間の相関係数を算出し，互いに 相関の高い潜在因子の組合せを見出す.

といった $2 つ の$ 機能をもつが, 特に, a) の機能は数量 化 II 類で使用する潜在因子を選定するうえで重要なもの となる. b) の機能については 6. で述べるので，ここで は, a) の分析結果について説明する.

図一6 (a)，(b) に対象領域内の全個体に対する個体 数量散布図とトレーニングデータのみの個体数量散布図 を示す. また, 図一6 (c) （e）には対象領域内の全個 体に対するカテゴリ一数量散布図を示す．なお,・第 1 軸 ～第 3 軸までの固有值が $\lambda_{1}>\lambda_{2}>\lambda_{3}>\left(\lambda_{1}=0.404, \lambda_{2}=\right.$ $\left.0.357, \lambda_{3}=0.253\right)$ であり，かつ第 3 固有值は第 1 , 第 2 固有値に比べて比較的小さいことから，ここでは，第 1 軸と第 2 軸で構成される特性空間内で分析した結果を 示す.

図一6 (a)，(b) をみるとトレーニングデータが全デー タの個体に対して偏った分布を示す．このことは，設定 した潜在因子によって畑地のもつ性質が説明付けられる ことを示唆する．また，図一6 (c) のカテゴリー数量散 布図では，その分布状態は全体的に散在した傾向にある が，土壌因子のみに着目したカテゴリ一数量散布図をみ ると，潜在的に畑地の適性に関連性がある「黒ボク土」, 「粗粒黒ボク土」といった因子が原点付近に位置してい る.この空間位置に対応する衛星データ因子のカテゴ

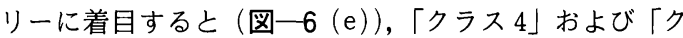

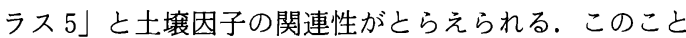
は表一1で示した数量化 II 類の分析結果として「黒ボク 土」,「粗粒黒ボク土」および「クラス 4」,「クラス $5 」$ といったカテゴリーが正の值を示すことからも説明付け られる. 数量化によって見出される特性空間内の分布の 違いから, 衛星データと質的な要因である他の潜在因子 


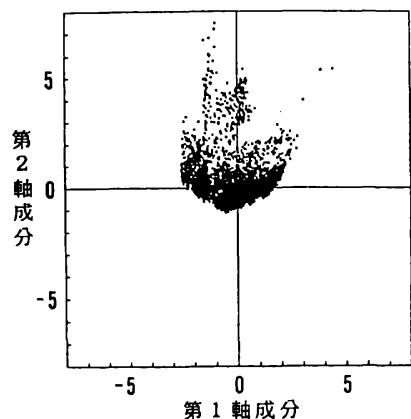

(a) 評価对象領域内の全個体

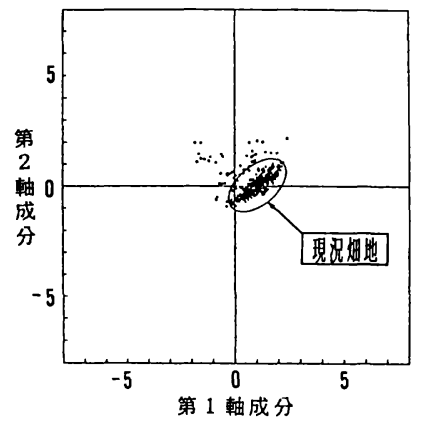

(b)トレーニンタデータのみ

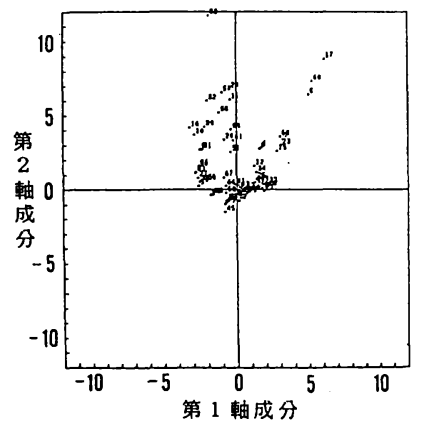

(c) 全潜在因子

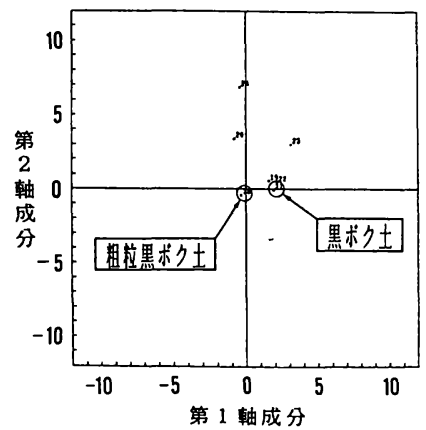

(d) 土蟺因子

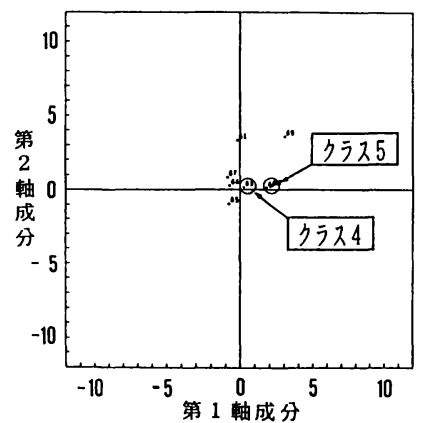

(e) 衛星テータ因子
注 1) (a), (b)個体数量散布図 (c)（ e ）：カテゴリー数量散布図

2）カテゴリ一数量散布図は, 紙面の 都合上，表一2で示した 9 つの潜 在因子を用いて数量化四類による 分析を行った結果を示す.

\section{図一6 数量化且類による分析}

との間を間接的に説明付けることができる.

\section{6. 分級評価図の作成と精度検証}

\section{（1） ミニマックス 2 群判別}

畑地適性の「有・無」という2つの質的な外的基準が ゼの程度説明されるのかといった統計指標の 1 つに表一 2 で示した相関比（=外分散／全分散）が挙げられる. 数量化理論 II 類の検討結果では, 相関比は非常に小さい 值を示したが，これは図一7に示すように畑地のトレー ニングデータと評価対象データが正規分布とならず，全 分散が大きくなったためである.このように分析対象 データが正規分布に従わない場合には, 相関比によって 2 群判別性能を評価することは適切ではない．そこで本 研究では畑地適性の「有・無」についてミニマックス 2 群判別の考え方を適用, 評価することとした. 2 群判別 の精度を表わすミニマックス解としての的中率 $P$ と判 別区分点 $\alpha$ の算出問題について考える. 図一 8 に示すよ うに累積頻度曲線を作成し，

$$
\left.\begin{array}{l}
F_{A}(Y)=1-\int_{-\infty}^{Y} f_{A}(y) d y, \quad\left(\int_{-\infty}^{+\infty} f_{A}(y) d y=1\right) \\
F_{B}(Y)=\int_{-\infty}^{Y} f_{B}(y) d y, \quad\left(\int_{-\infty}^{+\infty} f_{B}(y) d y=1\right)
\end{array}\right\}
$$

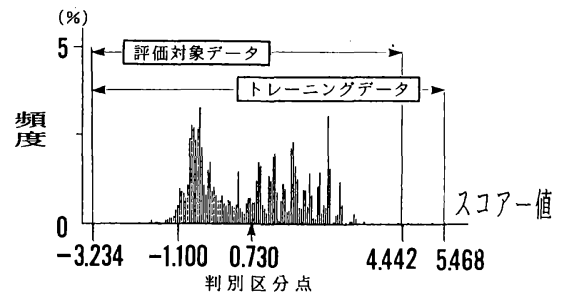

図一7 数量化I類によるスコアー値の分布状態

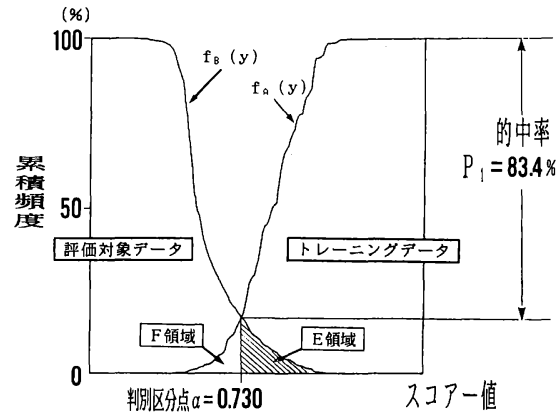

図一8 判別区分点および的中率の算出結果

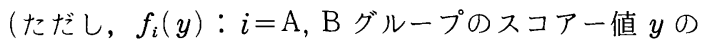
度数）と表現するとき, 2 つの累積頻度分布 $F_{i}(Y), i$ $=\mathrm{A}, \mathrm{B}$ の交点が求める判別区分点 $\alpha$ となる. すなわち, 
表一3 数量化回類を用いた相関係数の算出結果

\begin{tabular}{|c|c|c|c|c|c|c|c|c|}
\hline & 衛星 & 土淁 & 頹斜区分 & 標高 & 斜面方伈 & 她形分類 & 起伏量 & 戞層地㙏 \\
\hline 衛星データ & - & & & & & & & \\
\hline 土壌 & 0.606 & - & & & & & & \\
\hline 傾斜区分 & 0.397 & 0.245 & - & & & & & \\
\hline 標高 & 0.725 & 0.508 & 0.535 & - & & & & \\
\hline 斜面方位 & 0.468 & 0.603 & 0.191 & 0.491 & - & & & \\
\hline 地形分類 & 0.548 & 0.864 & 0.827 & 0.575 & 0.640 & - & & \\
\hline 起伏量 & 0.415 & 0.253 & 0.001 & 0.540 & 0.225 & 0.747 & - & \\
\hline 表層地質 & 0.325 & 0.001 & 0.346 & 0.329 & 0.819 & 0.892 & 0.001 & - \\
\hline 谷密度 & 0.061 & 0.063 & 0.101 & 0.105 & 0.105 & 0.103 & 0.093 & \\
\hline
\end{tabular}

表一4 使用する潜在因子の違いに伴う的中率の変化

\begin{tabular}{|c|c|c|c|c|c|c|c|c|c|}
\hline ケース名 $\rightarrow$ & A & B & $\mathrm{C}$ & D & E & $\mathrm{F}$ & G & $\mathrm{H}$ & \\
\hline 1衛星デー夕因子 & 0 & 0 & 0 & $\mathrm{O}$ & 0 & 0 & 0 & 0 & 0 \\
\hline 2土墥因子 & $\mathrm{O}$ & $\mathrm{O}$ & O & $\mathrm{O}$ & $\mathrm{O}$ & O & $\mathrm{O}$ & $\mathrm{O}$ & 0 \\
\hline 3/傾斜区分因子 & 0 & 0 & O & $\mathrm{O}$ & 0 & 0 & $\mathrm{O}$ & 0 & \\
\hline (4)標高因子 & 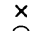 & O & 은 & $\mathrm{O}$ & ○ & ○ & 0 & $x$ & $\times$ \\
\hline (5)傾斜区分因子 & $\mathrm{O}$ & $\mathrm{O}$ & c & 은 $+x-1$ & O & 0 & $x$ & $x$ & $\dot{x}$ \\
\hline 6)地形分類因子 & $x$ & 0 & o & 0 & 0 & $x$ & $x$ & $x$ & $x$ \\
\hline 7)起伏盟因子 & 0 & $\mathrm{O}$ & $\mathrm{O}$ & 0 & $x$ & $x$ & $x$ & $x$ & $x$ \\
\hline 孆因子 & 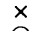 & $\mathrm{O}$ & 0 & $x$ & $x$ & $x$ & $x$ & $x$ & $x$ \\
\hline 公密度因子 & 0 & 0 & $x$ & $x$ & $x$ & $x$ & $x$ & $x$ & $\lambda$ \\
\hline 的中率P1 & & & & & & & & 90.5 & 94.6 \\
\hline
\end{tabular}

注） $\mathrm{O}$ : 使用する潜在因子、 $\mathrm{x}$ : 便用しない潜在因子

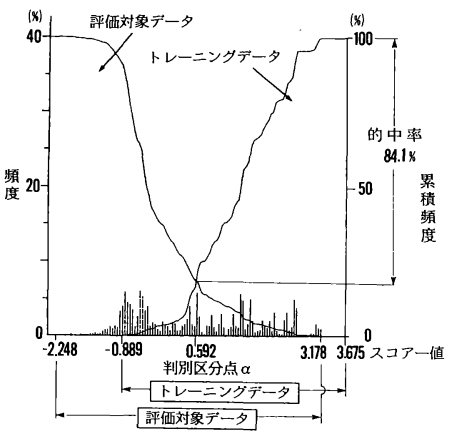

(a) ケース A

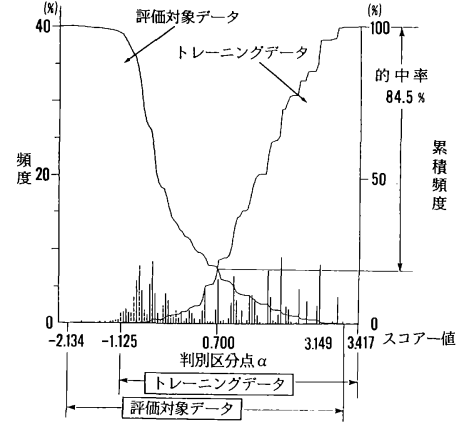

(b) ケース F

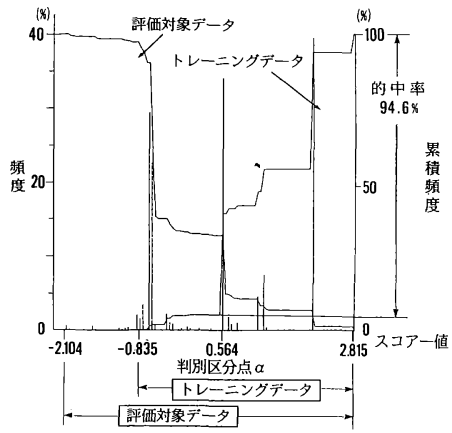

(c) ケース 1

図一9 使用する潜在因子の違いに伴う個体の分布状態の比較

$\mathrm{A}$ グループの領域 : $Y \geqq \alpha$

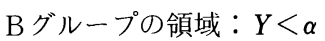

であり，このとき判別の度合いを表わす的中率 $P$ は，

$P=1-F_{i}(\alpha) \quad(i=\mathrm{A}, \mathrm{B})$

として求められる.なお,この $P$ の值は一般解 (厳密解) であり, 後述する離散解 $P_{1}$ と区別して扱う必要がある.

（2）的中率と判別精度について

本研究で取り扱う適地評価問題は，たとえば図一8に 示したようにトレーニングデータと評価対, 象データの ラップ部分の問題に帰着される. 図一7で定義される $\mathrm{E}$ 領域, $\mathrm{F}$ 領域の説明は後述する分級評価図の写真一1の 凡例に示すとおりである.ここで $\mathrm{E}$ 領域に入る個体，す なわち「畑地適性・有」とみなされる個体の判別精度は, あくまでも教師データとして設定した実際の畑地グルー プとの類似性という観点から間接的, 客観的に評価する ほかはない。したがって, 次式（3）で示すように畑地 グループのデータが判別区分点によって畑地適性「無」 のグループに誤判別される割合をもって, 判別の精度指 標 $P_{1}$ とみなすことができる.

$$
P_{1}=1-K_{F} / K_{a}
$$

ここで, $K_{F}$ : 図一9のF領域に判別される個体数

$K_{a}$ : トレーニングデータの全個体数

定義上 $P_{1}$ の值は一般解 (厳密解) としての的中率 $P$ と一致するはずであるが, 当然の結果としてピクセル単 位の離散的な解 $P_{1}$ との誤差は生じる. 本研究では後述 する分級評価図の表示形態も考慮し, 適地判別精度は厳
密解 $P$ ではなく, ピクセル単位でとらえる離散解 $P_{1}$ で 表現することとした。

（3）使用する潜在因子の違いに伴う的中率の変化

分級評価図は設定した潜在因子を用いて機械的に作成 することができる，したがって，設定する潜在因子の違 いによって的中率がどのように変化するのかといったこ とは重要な問題となる.そこで, 本研究では次の検討ケ一 スを設定し，的中率の変動を調べた.

ケース A : 5. (3) で述べた数量化 III 類の機能 b) を 用いて，潜在因子間の相関係数を算出する. 高い相関を 示す 2 つの潜在因子があれば, 数量化 II 類で算出した偏 相関係数の小さい方の潜在因子を削除する.

ケースB ケース I：ケースAと比較するために数量 化 II 類で算出した偏相関係数の小さいものから順に潜在 因子を削除する。

まず，ケースAの検討として，数量化類を用いて潜 在因子間の相関係数を算出した結果を表一3に示す. 表 中，相関係数が高いものについて枠で囲ってある.この うち, 数量化 II 類の偏相関係数の順位の高いものは採用 するものとすると, 地形分類, 表層地質, 標高因子が削 除される．起伏量因子は，地形因子が除去されるので残 される. 残された 6 つの潜在因子を用いて, ミニマック ス判別を行った結果を図一9（a）に示す。ケースBの状 態（図一8）と比べて顕著な違いはない.

また，ケースA〜ケース I までについて，潜在因子消 去過程で算出された的中率の值を表一 4 にまとめて整理 
した。ケース Aの的中率は $84.1 \%$ であり，すべての潜 在因子を用いたケースBの的中率 $83.4 \%$ より $0.7 \%$ 高 い。この違いは分級評価図上で，ケース $\mathrm{A} の$ 方が適地之 して判別される画素数が 10 画素少なくなる程度であり， ケース A とケース Bでの有意な差はないといえる.また， 図一8で示したように個体の分布状態は正規分布に従っ ていないことから，的中率の有意差検定を行うことは信 頼性の点で得策とはいえない。ケースC一ケース Gにつ いても的中率の変動はほとんどなく, 有意な差は認めら れない。参考までにケースC〜ケースGのうちで的中率 の最も高いケースFの個体の分布状態を示したものを図 -9 (b) に示す. 図一9 (a) と比較しても顕著な違い はない。

一方，ケース Hとケース Iではかなり高い的中率を示 すが，これは図一9（c）からわかるように使用する潜在 因子が少ないためにスコア一值の分散が極端に大きくな り, 単なる数学上の処理結果として的中率が高くなった にすぎず，畑地を説明する潜在因子として適切とはいえ ない.

以上をまとめると，使用する潜在因子の違いによって 的中率の変動について次の 2 点がわかった.

(1) 互いに相関が高い潜在因子をあらかじめ除去する と的中率は若干増加するが，有意な差は認められなかっ た．分級評価図上では，適地として判別される簓所がす ベての潜在因子を用いた場合に比べて，数画素が少なく なる程度である。

(2) 使用する潜在因子が極端に少なくなると，的中率 の信頼性はない.

ケース $\mathrm{A} \sim ケ ー ス \mathrm{G}$ までの的中率には有意な違いは認 められず，現実問題として最適な潜在因子を選定するこ とは困難といえる。しかし，的中率の大小によって，分 級評価図上では十数画素の違いが現わ机ることから，少 なめに適地を抽出する場合には高い的中率を示す潜在因 子を用い, その逆の場合には低い的中率を示す潜在因子 を用いるといったように評価者の柔軟な対応が必要とな る，得られる分級評価図を現地へフィードバックするこ とによって評価者自らが，結果の妥当性を検証すること が不可欠な要素となることはいうまでもない。

\section{（4）現状型分級評価図の作成}

実際に分級評価図を作成する際には，潜在因子モデル に汎用性をもたせるうえで，前述したケースAのように 数量化 III 類を通じて選定される潜在因子の組合せを優先 して採用することが適切であるといえる。そこで，ケー ス $\mathrm{A}$ の潜在因子を用いて現状型分級評価図を作成した例 を写真一1 に示す.

図の表示色は凡例に示す意味をもち，背景には地形図 をスキャナーで読み取ってディジタル化した画像データ
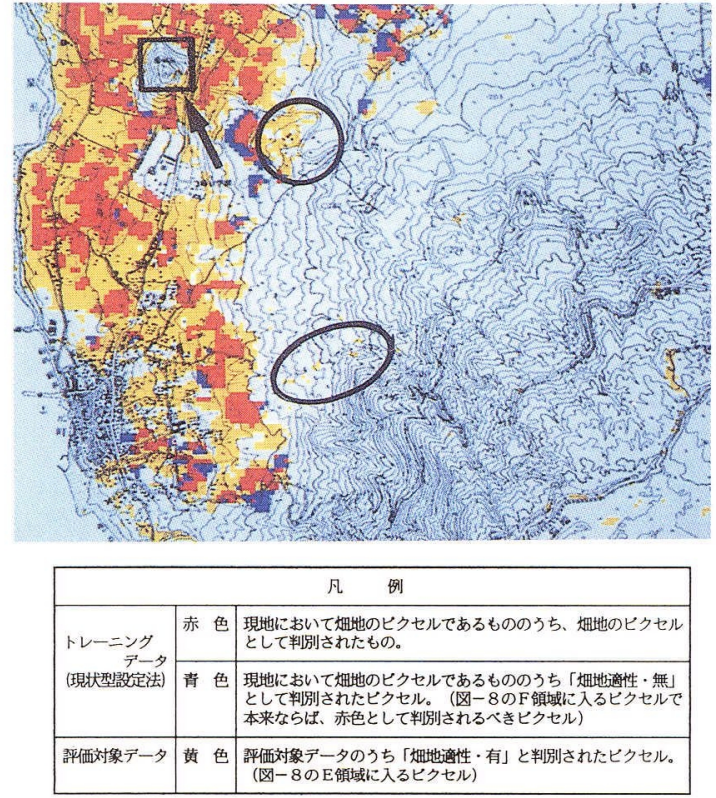

写真一1 現状型分級評価図

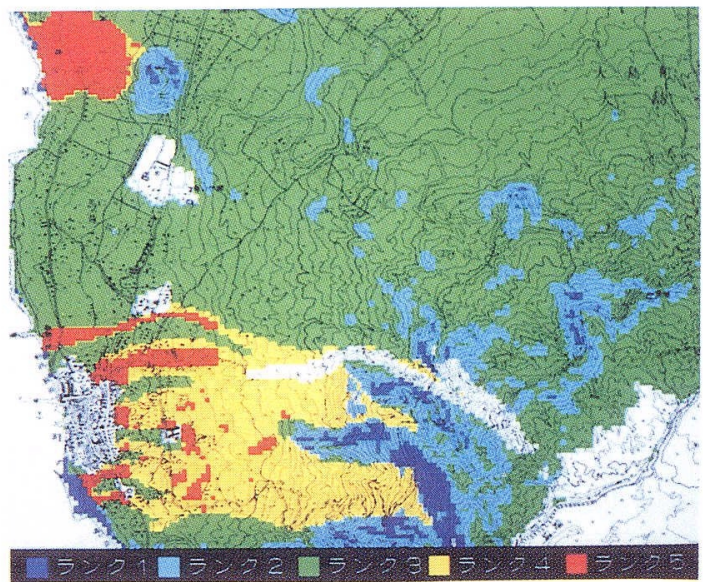

(国土庁土地条件分級詊価基淮 ${ }^{13}$ を参照)

ランク 1 (畑地適性小) いランク 5 (畑地適性大)

写真一2 重み付け最適化手法による分級評価図の例

を用い，図上での位置と等高線や周囲の地形の関連性を 判断できるような支援型の情報形態となるよう配虑し た。また，比較のために従来手法として国土庁で提案さ れた土地条件分級評価基準をもとに作成した畑地適性分 級評価図の一例を写真一2に示す ${ }^{13}$. この手法の詳細に ついては割愛するが，種々の評価プロセスを通じてラン ク分けされた分級評価図と比較して潜在因子モデルの 2 群判別による評価図のほうが，現状の土地の状況と整合 がとれており，農地振興計画図の作成等，土地利用計画 策定段階における基礎資料として十分に利用できる。た 
とえば，写真一1に抽赤色の部分は畑地として保全 し，青色の部分は他の土地利用に転換していき，さらに 黄色の部分は今後農地振興地域として計画するといった 基礎評価を加えることができる。

また，写真一1の○印で示した箇所は南向きの斜面で 日当りもよく, 畑地としての適性があることが現地調査 の結果確認されており，白地図だけからでは判断できな いような適地の抽出／評価に潜在因子モデルは有効であ ることがわかる.さらに, 衛星データの地上分解能に対 応する画素単位 (TM データ：約 $30 \mathrm{~m} /$ 画素) でこの ような評価が加えられ，土地利用計画策定段階において 精度の面からみても十分に実用に供するものといえる。

\section{7. 規範型分級評価と仮定型分級評価}

\section{（1）規範型分級評価}

潜在因子モデルを用いて規範型分級評価図を作成した 結果を写真一3 に示す (色の意味は写真一1 と同じ). 写 真中, 矢印で指示した矩形領域が規範的性質を内包した

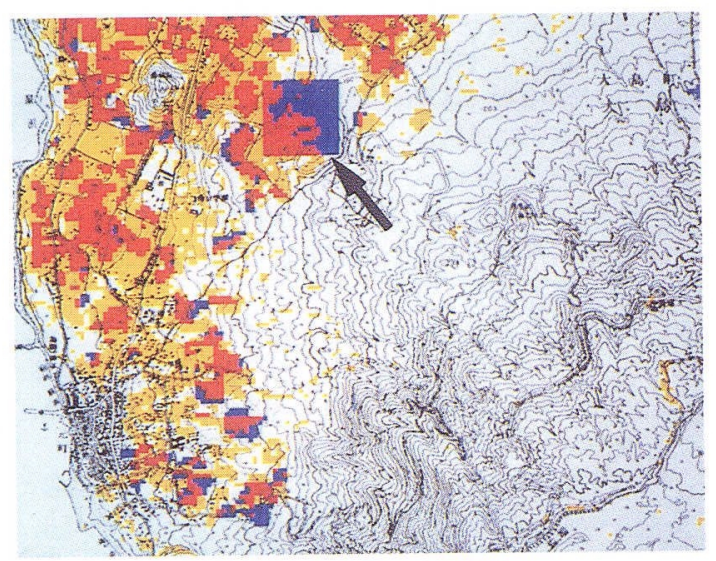

写真一3 規範型分級評価図

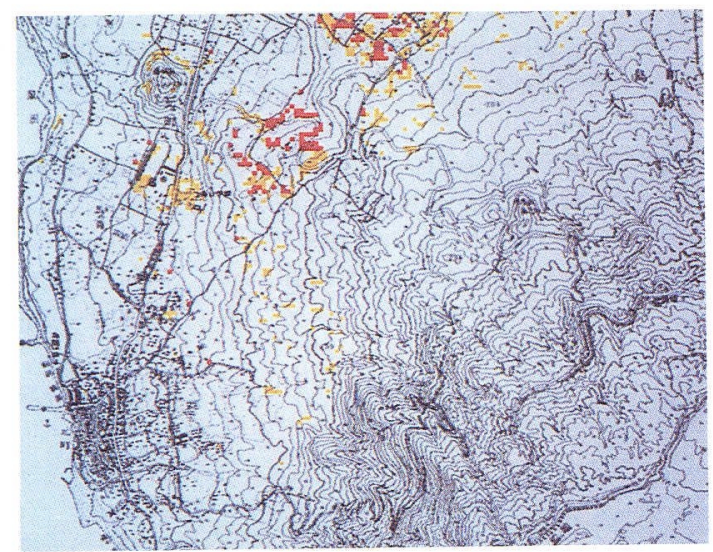

(差画像：現状型分級評価結果一規範型分級評価結果)

写真一4 規範的トレーニングデータを用いることによって新た に適地として反応した画素
トレーニングエリアである. 既存の農地振興区域図をも とに, 畑地としての営力がある領域とみなし, 現状型卜 レーニングデータを加えることによって規範型トレーニ ングデータとした．写真一1の現状型分級評価図に比べ て, 評価図中央から上部にかけて適地が多く現われてい ることがわかる。

さらに，現状型分級評価図との違いをより詳細によら えるために，潜在因子モデルでは新たに適地として反応 した箇所だけを抽出した評価図を作成するこことができ る.その結果が写真一4である. 規範的に設定するトレー ニングデータをさまざまに変えることによって，このよ うな評価図が容易に作成でき, 多角的な視点から分級評 価が行える.

\section{（2）仮定型分級評価}

仮定型分級評価の適用事例として, 写真-1の口印で 指示される領域（東西方向 6 画素×南北方向 5 画素：約 $180 \mathrm{~m} \times 150 \mathrm{~m}$ 四方）を設定した.この30 画素の領域は, 等高線をみてもわかるように傾斜が急であり, 現状型お よび規範型分級評価では適地として反応しなかった䈏所 である。そこで，「傾斜区分因子」を30画素すへてにつ いて「0度〜30 度」のほぼ平坦なカテゴリーに改変（仮 定) する。トレーニングデータおよび最適潜在因子は, 現状型分級評価で設定したものを用いる.

ただし, 衛星データ因子については, 画像濃度值を改 変させることはできないため, 仮定型分級評価では使用 できないことはいうまでもない.

傾斜区分因子の改変前と改変後の画素（個体）に付与 された数量を図一10に示す。このとき，判別区分点 (0.700) を境にして適地に変わった画素をハッチング で示してある. 30 画素のうち 25 画素が適地に変わって いる.この周辺は畑地としての土壌も肥えており, 周辺 にも畑地が存在することから，妥当な結果が得られてい る.

\begin{tabular}{|c|c|c|c|c|c|c|}
\hline & a & b & c & d & $\mathrm{e}$ & $f$ \\
\hline & 0.493 & 0.493 & 0.441 & 0.473 & 0.473 & 0.473 \\
\hline & 0.493 & 0.493 & 0.493 & -0.143 & -0.277 & 0.473 \\
\hline & 0.493 & 0.493 & 0.493 & -0.611 & -0.277 & 0.473 \\
\hline & 0.230 & 0.230 & 0.230 & -0.559 & -0.673 & -0.806 \\
\hline & 0.230 & 0.230 & 0.230 & -0.366 & -0.299 & 0.195 \\
\hline
\end{tabular}

\begin{tabular}{|c|c|c|c|c|c|c|}
\hline & a & b & c & d & e & f \\
\hline A & 1.683 & 1.683 & 1.633 & 1.662 & 1,662 & 1.662 \\
\hline B & 1.683 & 1.683 & 1.683 & 0.913 & 0.913 & 1.662 \\
\hline C & 1.883 & 1.683 & $1<683$ & 0.353 & 0.913 & 1.662 \\
\hline D & 1.419 & 1. 419 & 1.419 & 0.403 & 0.382 & 0.382 \\
\hline E & 1.419 & 1. 419 & 1.419 & 1.152 & 0.382 & 1. 251 \\
\hline
\end{tabular}

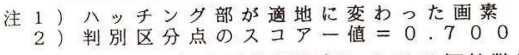
図-10 仮定型分級評価における個体数量の変化 


\section{8. 研究の成果}

本研究の成果は, 以下の 4 点にまとめられる.

（1）土地に内在する価值を存在価値, 潜在価値, 使 用価值といった「空間価值」の観点からとらえ, 存在価 值, 潜在価値の 2 つの視点から土地利用計画策定段階に おける「土地評価」の考え方を整理し, 潜在因子モデル の全体構成を明確にした.この検討過程において土地分 級評価手法に内在する問題点を抽出整理し, 潜在因子モ デルが具備すべき要件を明確にした。

（2）衛星マルチスペクトルデータをはじめ地形, 表 層, 土壌といった種々の情報を土地に内在する潜在因子 として定義し, 衛星マルチスペクトルデータを土地に内 在する潜在因子として組み込むことができる「分級」と 「評価」の概念を提案した。

（3）従来から考案されている分級評価手法と潜在因 子モデルから得られた分級評価図（テスト評価主題：畑 地適性評価）を比較することによって，ランク分けされ た分級評価結果の曖昧性を排除し，ミニマックス 2 群判 別の有効性を示すことができた。

（4）トレーニングデータの設定方法の違いによって 現状型, 規範型, 仮定型といった 3 つの評価プロセスを 提案し，人間の意思決定プロセスに反映させることが可 能な柔軟かつ発展性のあるモデルとすることができた。

\section{9. 今後の展望}

本研究における今後の展望を次の 3 点に整理する.

（1）本研究ではテスト評価主題として「畑地適性分 級評価」を取り上げたが，今後は土地に内在する潜在因 子からの評価アプローチとして将来にわたる住居専用地 区, 商工業用地区等の開発問題や地域計画図, 土地条件 図等の作成について多角的な検討を行う.

(2) 現在, フランスの SPOT, アメリカの LANDSAT, そしてわが国の MOS-1 等, 種々の衛星から観 測されるマルチスペクトルデータが入手できるように なっている.このような複数の衛星デー夕を潜在因子モ デルに適用することによって地上分解能やデー夕観測時 期の違い等に伴う分級評価結果への影響をとらえ, 複数 の衛星データの代替的な利用等, さまざまな利用方法を 検討する.

（3）パーソナルコンピュータ上で潜在因子モデルが 稼㗢できるようにシステム開発を進める. 特に, 繰り返 し処理を要する規範型および仮定型評価では有効とな る.

\section{0. むすび}

土地評価問題や土地利用計画等に関する研究は専門分
野ごとに複雑多岐に分かれており，その数は枚挙にいと まがない.ここで報告した内容は，これらの研究領域の ほんの一部にすぎないものではあるが, 衛星マルチスペ クトルデータを含めた先端技術の適用と実利用化を含 め，さまざまな国土の評価／計画にかかわる応用技術の 開発，展開への参考亡なることを期待したい. 多くの分 野にわたる専門家の方々のご批判とご叱正を仰ぐことが できれば幸いである。

最後に本研究を進めるにあたって, 貴重な資料を提供 してくださった関係各位に深く御礼申し上げます.

1）出口近士・沼田 實・亀井敏裕：ランドサットデータを 利用した土地利用計画支援のための土地条件図の作成, 土木学会論文集, No. $371 / \mathrm{IV}-5$, pp. $97 \sim 106,1986$ 年 7 月.

2) Carol A. Johnston and John Bonde : Quantitative Analysis of Ecotones Using a Geographic Information System, Photogrammetric Engineering and Remote Sensing, Vol. 55, No. 11, pp. 1643〜1647, 1989.

3）青山吉隆 : 土地利用モデルの歴史と概念, 土木学会論文 集, No. 347/IV-1，pp. 19 28，1984 年 7 月.

4) 中村英夫編著 : 土木学会編・新体系土木工学 50 国土調查 一地域の調查と分析一, 技報堂出版, 1984 年.

5）大林成行 - 小島尚人・前田宗宏：衛星りモートセンシン グデータを用いた分級評価手法の問題点, 土木学会第 44 回年次学術講演会講演概要集第 4 部門, pp. 480 481, 1989 年 10 月.

6）大林成行・小島尚人・不原利信：衛星リモートセンシン グデータを適用した分級評価支援システムに関する考察, 土木学会第 17 回関東支部技術研究発表会講演概要集, pp. $254 \sim 255,1990$ 年 3 月.

7）大林成行 - 小島尚人 - 笠 博義：斜面崩壊予測を対象と した衛星マルチスペクトルデータの実利用化について, 土木学会論文報告集, No. $415 / \mathrm{IV}-12$, pp. $71 \sim 80,1990$ 年 3 月.

8）堺毅・西川 肇，ほか：ランドサットデータ MSS データを用いた早川流域の斜面崩壊の研究一新崩壊地の 探索一, 日本リモートセンシング学会誌, Vol. 5, No.1, 1985 年.

9）大橋健一・青山吉隆 : 土木計画への数量化理論 II 類適用 の信頼度に関する実験的研究, 土木学会論文集, No. 353 / IV -2, pp. $67 \sim 74,1985$ 年 1 月.

10）村上幸利・箭内寛治：数量化法による転落型落石の危険 度評価, 土木学会論文集, No. 406/III-11, pp. 223～231， 1989 年 6 月.

11）森地 茂: 国土計画の基本的な課題, 土木学会誌別冊増 刊一国土計画一, pp. 25 29, 1989 年 11 月.

12）大林成行 : 土地分類基本調査, 成果図面一式, 大島 5 万 分の 1 , 東京理科大学出版会, 1989 年 10 月.

13）国土庁土地局国土調査課：メッシュデータに関する分級 評価基礎調査, 調查報告書一土地条件分級評価一, 1977 年 9 月.

(1990.5.14 • 受付) 